\title{
Effect of Culture Medium on Growth of Blue Green Algae
}

\author{
K.T. Thakare*, Maya Nadare and J.M. Parbat \\ Students of College of Agriculture, Nagpur, M.S., India \\ *Corresponding author
}

\section{A B S T R A C T}

\begin{tabular}{|l|}
\hline K e y w or d s \\
$\begin{array}{l}\text { Blue green algae, Culture } \\
\text { medium, Soil }\end{array}$ \\
\hline Article Info \\
\hline $\begin{array}{l}\text { Accepted: } \\
\text { 20 September } 2018 \\
\text { Available Online: } \\
\text { 10 October } 2018\end{array}$ \\
\hline
\end{tabular}

\section{Introduction}

Cyanobacteria, formerly called "Blue-Green Algae" are relatively simple, primitive life forms closely related to bacteria. Typically much larger than bacteria, they photosynthesize like algae. Depending upon the species, cyanobacteria occur as single cells, filaments of cells, or colonies. Cyanobacteria contain a characteristic pigment which gives the group their blue-green coloration. Blue Green Algae possess an autotrophic mode of growth like eukaryotic plant cells, metabolic system like bacteria and occupy a unique position. Cyanobacteria are extraordinarily diverse group of gram negative oxygenic, photosynthetic prokaryotes distributed in rice field. Cyanobacteria reproduce by asexual method like binary fission and fragmentation are the most common methods. Nitrogen fixing Blue Green Algae has been generally attributed to the release of nitrogenous compound, either by excretion or decomposition of the algal cells. The cyanobacteria fixes atmospheric nitrogen in anaerobic condition by means of specialized cells called heterocyst.

Nitrogen is one of the major components in every organism body forming components, which are proteins. Cyanobacteria are rich source of structurally novel and biologically active compound. BGA play a potential role in crop protection as herbicides, algaecides, nematicides, fungicides, bactericides and insecticides (Deviram, et al., 2011; Biondi et al., 2004) and release growth promoting substance like Auxines, Gibberlines, Cyatokinens and Abscisic acid (Gupta and Agrawal, 1973). Paddy soil of Vidarbha 
region was very rich in BGA (Cherian, 1983; Kolte and Goyal, 1985) and all the paddy field soil is rich in algal population (LathaMadhavi, 2014).

Several methods and basic culture media were developed in the late 1800 and early 1900s. Soil is the most important non-aqueous substrate for algae and cyanobacteria. Due to their high capacity for morphological and physiological adaptations to different environments, both algae and cyanobacteria often act as pioneer microorganisms in terrestrial ecosystems. Over a century ago algae were first studied in culture by Beijerinck, (1890) and he was the first person to work with axenic cultures. Beijerinck, Knop and Bristol made some modification in culture media that helped in improved growth of algae in artificial culture media. Chu-10, Bristol's and Tamiya's media has been successfully used for culturing of many algal species. Pringsheim (1946) suggested that the selection of a suitable culture media for isolation and successful cultivation of certain species of algae. The present study aims to find out effect of different growth media on growth of Blue Green Algae.

\section{Materials and Methods}

The present study was conducted in Plant Pathology laboratory, College of Agriculture, Nagpur during the year of 2016 - 2017. Blue Green Algae isolated from rice field soil samples and maintained for further studies.

\section{Sample collection, isolation and maintenance}

Rhizosphere soil samples were collected from eight different Taluka of Gondia districts from rice field. Soil samples collected from the surface layer, separate the inert material and placed in polythene bags. Carry the samples to laboratory and stored for further studies. 10 gm of each soil samples placed into $250 \mathrm{ml}$ conical flask with 100 fold dilution with distilled water and fixed with formaldehyde solution and incubate at 60 days. In another part one gram of soil samples placed into 250 $\mathrm{ml}$ conical flask containing different liquid culture medium and incubates for 60 days at room temperature under continuous illumination at 16 and 18 hour light and dark cycle at 2500 - 3000 lux light intensity provided by cool white fluorescent lamp for adequate growth of cultures. For each media four replicates were maintained to study population dynamic at interval of every 15 days on different algal media, flasks were observed daily for algal growth and observed the growth of cyanobacteria under binocular research microscope. After 12 to 15 days visible growth was observed then $6-7$ wet mounts from each flask were prepared by lifting the algal growth and suspended in nine $\mathrm{ml}$ sterilized distilled water in test tube, shaken vigorously to make a homogenous suspension. One $\mathrm{ml}$ of this suspension was seeded on an agar plate with the help of sterile pipette. The plate was observed regularly and isolated colonies were picked up and examined under microscope for morphological studies. These unialgal cultures were picked up from the plate and transferred to algal slants.

\section{Growth of BGA on culture media}

After preparation of different six media, 100 $\mathrm{ml}$ quantity of each media transferred in different $250 \mathrm{ml}$ of conical flasks separately. The media containing flask inoculated with the previously isolated algal culture. Four replications were maintained for each medium. These flasks were incubated under the white fluorescent light at room temperature with light and dark cycles for 60 days. The algal growths were observed in each 15 days and recorded the growth of BGA at $15,30,45$ and 60 days of interval. 


\section{Medium used for study}

The entire six medium used for the growth of BGA during experiment Viz. Modified Bristol's Medium (Bristol, 1949), Fogg's Medium (Fogg's. 1965), BG-11 Medium (Rippka et al., 1979), Pringsheim's Medium (Pringsheim, 1946), Allen and Arnon Medium (Allen and Arnon, 1955) and Chu's 10 Medium (1942).

\section{Results and Discussion}

\section{Effect of culture medium on Blue Green Algal flora}

All the three culture medium was tested for growth of blue green algae and observed that the all culture medium supported better growth of BGA during investigation.

The average numbers of Blue Green Algal colonies isolated using different culture media are presented in table 1 ( $a, b, c$ and d). Total six culture medium were used for isolation Blue Green Algal colonies and recorded the observation at interval of $15,30,45$ and 60 days after inoculation.

Among the media used the highest number of algal colonies were found in Allen and Arnon medium $(42.09,45.56,47.02$ and 48.51) at 15 , 30,45 and 60 days after inoculation followed by Modified Bristol's medium (33.54, 45.55, 46.37 and 47.69) and Pringsheim's medium (32.76, 40.45, 43.41 and 47.19).

The other media used recorded moderate number of Blue Green Algal colonies whereas Fogg's medium $(12.49,21.04,28.94$ and 39.56) was least preferred for the growth of BGA. Out of eight taluka Sadak Arjuni (33.54) harbours highest colonial growth at 15 DAI followed by Salekasa (31.23) and Deori (31.57) taluka while lowest colonies observed in Tirora (22.14). The data indicated that different soils exhibited variation in Blue Green Algal Population.

Table.1 (a) Number of Blue Green Algal colonies on different algal media at 15 DAI

\begin{tabular}{|l|l|c|c|c|c|c|c|c|c|}
\hline $\begin{array}{c}\text { Sr. Sampling } \\
\text { No. }\end{array}$ & \multicolumn{3}{|c|}{ Number of Blue Green Algal colonies on different media/ g } & Total & mean \\
\hline & $\begin{array}{c}\text { Modified } \\
\text { bristol } \\
\text { medium }\end{array}$ & $\begin{array}{c}\text { Fogg's } \\
\text { medium }\end{array}$ & $\begin{array}{c}\text { BG-11 } \\
\text { medium }\end{array}$ & $\begin{array}{c}\text { Pringsheim } \\
\text { medium }\end{array}$ & $\begin{array}{c}\text { Allen } \\
\text { and } \\
\text { Arnon } \\
\text { medium }\end{array}$ & $\begin{array}{c}\text { Chu's- } \\
\text { 10 } \\
\text { medium }\end{array}$ & & \\
\hline & & & & & & & & \\
\hline $\mathbf{1}$ & Salekasa & 36.83 & 10.52 & 29.25 & 39.78 & 47.36 & 23.67 & 749.72 & 31.23 \\
\hline $\mathbf{2}$ & Deori & 39.46 & 21.04 & 30.25 & 34.2 & 42.1 & 22.36 & 757.76 & 31.57 \\
\hline $\mathbf{3}$ & Amgaon & 27.62 & 11.84 & 28.94 & 38.15 & 42.09 & 28.94 & 710.38 & 29.59 \\
\hline $\mathbf{4}$ & Goregaon & 35.51 & 15.78 & 27.62 & 32.89 & 42.1 & 27.62 & 726.17 & 30.25 \\
\hline $\mathbf{5}$ & Gondia & 35.52 & 7.89 & 38.15 & 34.25 & 46.04 & 22.36 & 736.9 & 30.7 \\
\hline $\mathbf{6}$ & Tirora & 26.31 & 10.52 & 24.99 & 19.73 & 32.89 & 17.09 & 531.46 & 22.14 \\
\hline $\mathbf{7}$ & $\begin{array}{c}\text { Sadak } \\
\text { Arjuni }\end{array}$ & 42.1 & 17.1 & 31.57 & 38.15 & 44.73 & 27.62 & 805.44 & 33.54 \\
\hline $\mathbf{8}$ & $\begin{array}{c}\text { Arjuni } \\
\text { Morgaon }\end{array}$ & 24.99 & 5.26 & 28.94 & 24.99 & 39.47 & 21.04 & 578.82 & 24.11 \\
\hline & Avarage & 33.54 & 12.49 & 29.96 & 32.76 & 42.09 & 23.83 & & \\
\hline
\end{tabular}


Table.1 (b) Number of Blue Green Algal colonies on different algal media at $30 \mathrm{DAI}$

\begin{tabular}{|c|c|c|c|c|c|c|c|c|c|}
\hline \multirow{2}{*}{$\begin{array}{l}\text { Sr. } \\
\text { No. }\end{array}$} & \multirow{2}{*}{$\begin{array}{l}\text { Sampling } \\
\text { sites }\end{array}$} & \multicolumn{6}{|c|}{ Number of Blue Green Algal colonies on different media/ g } & \multirow[t]{2}{*}{ Total } & \multirow[t]{2}{*}{ Average } \\
\hline & & $\begin{array}{c}\text { Modified } \\
\text { bristol } \\
\text { medium }\end{array}$ & $\begin{array}{l}\text { Fogg's } \\
\text { medium }\end{array}$ & $\begin{array}{l}\text { BG-11 } \\
\text { medium }\end{array}$ & $\begin{array}{l}\text { Pringsheim } \\
\text { medium }\end{array}$ & $\begin{array}{c}\text { Allen } \\
\text { and } \\
\text { Arnon } \\
\text { medium }\end{array}$ & $\begin{array}{c}\text { Chu's- } \\
10 \\
\text { medium }\end{array}$ & & \\
\hline 1 & Salekasa & 57.89 & 26.31 & 47.36 & 47.36 & 56.57 & 44.73 & 1120.94 & 46.7 \\
\hline 2 & Deori & 46.04 & 31.57 & 42.09 & 40.78 & 46.05 & 35.52 & 968.29 & 40.34 \\
\hline 3 & Amgaon & 44.72 & 17.1 & 39.46 & 40.78 & 46.1 & 38.15 & 905.34 & 37.72 \\
\hline 4 & Goregaon & 46.04 & 31.57 & 35.52 & 43.41 & 40.78 & 35.52 & 931.43 & 38.8 \\
\hline 5 & Gondia & 46.04 & 14.46 & 43.41 & 42.1 & 46.03 & 30.26 & 889.29 & 37.05 \\
\hline 6 & Tirora & 39.47 & 15.78 & 36.83 & 32.88 & 38.15 & 26.31 & 757.75 & 31.57 \\
\hline 7 & $\begin{array}{l}\text { Sadak } \\
\text { Arjuni }\end{array}$ & 43.41 & 22.36 & 43.41 & 43.41 & 48.68 & 38.15 & 957.76 & 39.9 \\
\hline 8 & $\begin{array}{l}\text { Arjuni } \\
\text { Morgaon }\end{array}$ & 40.78 & 9.2 & 42.1 & 32.89 & 42.1 & 30.25 & 789.35 & 32.88 \\
\hline & Avarage & 45.55 & 21.04 & 41.27 & 40.45 & 45.56 & 34.86 & & \\
\hline
\end{tabular}

Table.1 (c) Number of Blue Green Algal colonies on different algal media at 45 DAI

\begin{tabular}{|c|c|c|c|c|c|c|c|c|c|}
\hline \multirow{2}{*}{$\begin{array}{l}\text { Sr. } \\
\text { No. }\end{array}$} & \multirow{2}{*}{$\begin{array}{l}\text { Sampling } \\
\text { sites }\end{array}$} & \multicolumn{6}{|c|}{ Number of Blue Green Algal colonies on different media/ g } & \multirow[t]{2}{*}{ Total } & \multirow[t]{2}{*}{ Average } \\
\hline & & $\begin{array}{c}\text { Modified } \\
\text { bristol } \\
\text { medium }\end{array}$ & $\begin{array}{l}\text { Fogg's } \\
\text { medium }\end{array}$ & $\begin{array}{c}\text { BG-11 } \\
\text { medium }\end{array}$ & $\begin{array}{c}\text { Pringsheim } \\
\text { medium }\end{array}$ & $\begin{array}{c}\text { Allen } \\
\text { and } \\
\text { Arnon } \\
\text { medium }\end{array}$ & $\begin{array}{c}\text { Chu's- } \\
10 \\
\text { medium }\end{array}$ & & \\
\hline 1 & Salekasa & 59.2 & 38.15 & 52.62 & 53.94 & 57.82 & 51.31 & 1252.27 & 52.17 \\
\hline 2 & Deori & 48.68 & 38.15 & 43.41 & 44.73 & 47.36 & 42.1 & 1057.74 & 44.07 \\
\hline 3 & Amgaon & 39.46 & 18.41 & 35.52 & 36.83 & 40.78 & 36.83 & 831.44 & 34.64 \\
\hline 4 & Goregaon & 44.73 & 32.89 & 48.68 & 43.41 & 44.73 & 40.78 & 1020.95 & 42.53 \\
\hline 5 & Gondia & 51.31 & 27.62 & 44.73 & 47.36 & 49.99 & 39.46 & 1041.98 & 43.41 \\
\hline 6 & Tirora & 39.46 & 26.31 & 38.15 & 39.47 & 40.78 & 32.88 & 868.29 & 36.17 \\
\hline 7 & $\begin{array}{l}\text { Sadak } \\
\text { Arjuni }\end{array}$ & 47.36 & 31.57 & 47.36 & 44.73 & 51.31 & 40.78 & 1052.52 & 43.85 \\
\hline 8 & $\begin{array}{l}\text { Arjuni } \\
\text { Morgaon }\end{array}$ & 40.78 & 18.41 & 43.41 & 36.83 & 43.41 & 34.2 & 868.28 & 36.17 \\
\hline & Avarage & 46.37 & 28.94 & 44.24 & 43.41 & 47.02 & 39.79 & & \\
\hline
\end{tabular}


Table.1 (d) Mean no. of Blue Green Algal colonies on different algal media at 60 DAI

\begin{tabular}{|c|c|c|c|c|c|c|c|c|c|}
\hline \multirow{2}{*}{$\begin{array}{l}\text { Sr. } \\
\text { No. }\end{array}$} & \multirow{2}{*}{$\begin{array}{l}\text { Sampling } \\
\text { sites }\end{array}$} & \multicolumn{6}{|c|}{ Number of Blue Green Algal colonies on different media/ g } & \multirow[t]{2}{*}{ Total } & \multirow[t]{2}{*}{ Average } \\
\hline & & $\begin{array}{c}\text { Modified } \\
\text { bristol } \\
\text { medium }\end{array}$ & $\begin{array}{l}\text { Fogg's } \\
\text { medium }\end{array}$ & $\begin{array}{c}\text { BG-11 } \\
\text { medium }\end{array}$ & $\begin{array}{c}\text { Pringsheim } \\
\text { medium }\end{array}$ & $\begin{array}{c}\text { Allen } \\
\text { and } \\
\text { Arnon } \\
\text { medium }\end{array}$ & $\begin{array}{c}\text { Chu's- } \\
10 \\
\text { medium }\end{array}$ & & \\
\hline 1 & Salekasa & 60.52 & 49.99 & 55.25 & 59.2 & 60.52 & 53.94 & 1357.76 & 56.57 \\
\hline 2 & Deori & 47.36 & 40.23 & 46.04 & 46.04 & 48.67 & 43.41 & 1087.12 & 45.29 \\
\hline 3 & Amgaon & 43.41 & 38.15 & 44.73 & 46.04 & 44.73 & 42.1 & 1036.7 & 43.19 \\
\hline 4 & Goregaon & 46.04 & 38.15 & 48.68 & 44.73 & 46.04 & 42.1 & 1036.05 & 44.29 \\
\hline 5 & Gondia & 51.31 & 34.2 & 49.99 & 48.67 & 51.31 & 44.73 & 1120.93 & 46.7 \\
\hline 6 & Tirora & 39.47 & 38.15 & 40.78 & 43.41 & 4.78 & 39.46 & 968.3 & 40.34 \\
\hline 7 & $\begin{array}{l}\text { Sadak } \\
\text { Arjuni }\end{array}$ & 48.68 & 42.1 & 46.05 & 47.36 & 49.99 & 46.05 & 1120.96 & 46.7 \\
\hline 8 & $\begin{array}{l}\text { Arjuni } \\
\text { Morgaon }\end{array}$ & 44.73 & 35.52 & 43.41 & 42.09 & 46.04 & 40.78 & 1010.37 & 42.09 \\
\hline & Avarage & 47.69 & 39.56 & 46.87 & 47.19 & 44.01 & 44.07 & & \\
\hline
\end{tabular}

At 30, 45 and 60 days Salekasa (46.7, 52.17 and 56.57) taluka showed the highest colonies of Blue Green Algae followed by Deori (40.34 and 44.07) and at 60 DAI Gondia and Sadak Arjuni (46.7).

The data also indicated that the soils analyzed were rich in Blue Green Algal population. This study also indicated the role of different culture medium for isolation. The above study reveals that the paddy field of Gondia district were rich in Blue Green Algal isolates. Tiwari (1972) studied the Blue Green Algal flora of various satates of India and recorded more number of Algal floras in culture condition compared to natural condition. Gajbhiye (2010) reported maximum growth of BGA in BG-11 medium followed by Bristol's and Fogg's medium. Latha Madhavi (2014) observed the highest number of algal colonies in modified Bristol's medium followed by Beneck's and Tamiya's medium. BG-11 medium supported the growth of Lyngbya bipunctata properly and Allen and Arnon medium also supported the growth after 20 to 25 days while Fogg's and Zorrouk's medium supported the growth at very low rate (Nehul, 2014). Variation in the culture medium supporting the growth of Blue Green Algae have been reported by Sharma and Kerni (1992), Nehul (2014) and Das and Sharma (2015).

\section{References}

Allen, M. B. and D. I. Arnon, 1955. Studies on nitrogen fixing blue green algae. I. growth and nitrogen fixation in Anabaena cylindrca. Plant Physiol. 30: 366-372.

Beijerink, M.W. 1890. Cultureversuche mit Zoochlorellen, Lichegonidien anderen niedern Algen. Bot. Zeitung 48: 725-39, 741-54, 757-68, 781-85.

Biondi, N., R. Piccardi, M. C. Margheri, L. Rodolfi, G. D. Smith and M. R. Tredici, 2004. Evaluation of Nostoc strain ATCC 53789 as apotential source of natural pesticides. Appl. Environ. Biotechnol. 70:3313-3320.

Cherian, K. J., 1983. Studies on paddy field algae of Vidarbha region. Unpublished 
Ph. D. Thesis, submitted to the R. T. M. Nagpur Univ. Nagpur, Maharashtra, India.

Chu, S., 1942. The influence of the mineral composition of the medium on the growth of planktonic algae. I. methods and culture media. J. Ecol. 30: 284-325.

Das, K. and G. C. Sarma, 2015. Optimization of culture media for the growth of Anabaena spiroides and Nostoc punctiformae of Jorhat District, Assam. IOSR J. Pharma. Biol. Sci. 10 (2): 3741.

Deviram, G. V. N. S., S. G. Pant and R. G. Prasuna, 2011. Antimicrobial activity of pesticide adapted cyanobacteria on fungal pathogens of rice. European $J$. Exp. Bio. 1 (4):50-54.

Fogg, G., 1965. Algal culture and phytoplankton ecology. Univ. Wisconsin Press, Madison. Pp. 126.

Gajbhiye, P. R., 2010. Algalization studies in paddy. M. Sc. Thesis (Unpublished). Submitted to Dr. P.D.K.V. Akola. Pp. 24-26.

Gupta, A. B. and P. R. Agarwal, 1973. Extraction, isolation and bioassay of a gibberellin-like substance from Phormidium foveolarum. Ann. Bot. 37 (152): 737-741.

Kolte, S. O. and Goyal. S. K., 1985. Distributional pattern of Blue Green
Algae in rice field soil of vidarbha region of Maharashtra state. Phykos, 40: 156-162.

Latha Madhavi D, Raj Kumar. B and Sai Krishna. T., 2014. Choice of culture media for isolation of algae from soils of some rice fields. Phykos. 44 (2): 4453.

Nehul, J. N., 2014. Influence of various culture media on growth and production of carotinoide in a cyanobacterium Lyngbya bipunctata Lemm. Biosci. Dicsc. 5 (1): 60-63.

Pringsheim, E. 1946.Pure Cultures of Algae. Cambridge University Press, London. $119 \mathrm{Pp}$.

Rippka, R., J. Deruelles, J. B. Waterbury, M. Herdman and R. Y. Stanier, 1979. Generic assignments, strain histories and properties of pure cultures of cyanobacteria. J. Gen. Microb. 111: 161.

Sharma, B. M. and P. N. Kerni, 1992. Nitrogen fixing Blue Green Algae from rice field of Jammu and Kashmir. L. V. Gangawane (Eds), National Seminar on Bio-fertilizer Technology Transfer. Asso. Pub. New Delhi. Pp. 187-190.

Tiwari, G. L., 1972. A Study of the Blue Green Algae from Paddy field soil of India. Hydrobiologia. 39 (3): 335-350.

\section{How to cite this article:}

Thakare, K.T., Maya Nadare and Parbat, J.M. 2018. Effect of Culture Medium on Growth of Blue Green Algae. Int.J.Curr.Microbiol.App.Sci. 7(10): 2685-2690.

doi: https://doi.org/10.20546/ijcmas.2018.710.312 